\title{
SECULAR TRENDS AND LATITUDE GRADIENTS IN SEX RATIOS AT BIRTH IN THE FORMER SOVIET REPUBLICS
}

\author{
Victor Grech
}

Department of Paediatrics, Mater Dei Hospital, Malta

\begin{abstract}
Summary: Background: The male-female ratio at birth (M/F: male births divided by total births), which is anticipated to approximate 0.515 , has been shown to exhibit latitude gradients and secular trends. Methods: Annual national data for male and female live births for the 15 countries that comprise the former Soviet Union were obtained from the World Health Organisation for the period 1980-2009 (115,167,569 total live births) and analysed with contingency tables. Spearman correlation was also carried out to compare percentage annual gross domestic product growth (GDP\% - downloaded from the World Bank) and M/F. In this context, GDP\% is used as a measure for economic hardship or wellbeing within the populace. Results: There have been overall highly significant secular increases in $\mathrm{M} / \mathrm{F}(\mathrm{p}<0.0001)$ in the countries and regions investigated. $\mathrm{M} / \mathrm{F}$ is significantly lower in the three more northern regions (Russian Federation, Baltic States and Central Asia. M/F 0.51324, 0.51335-0.51314) than the two more southern regions (Southern Caucasus and Eastern Europe. M/F 0.51654, 0.51635-0.51672). There was a male excess of 113,818 live births. There was a significant positive correlation between GDP\% and M/F for Armenia, Azerbaijan and Uzbekistan. There was a significant negative correlation in Estonia. Conclusion: Previous studies have shown that improving socioeconomic conditions increase $\mathrm{M} / \mathrm{F}$, and the converse has also been demonstrated. This is a potential influence in this geographical area since this region has relatively recently emerged from communist rule and experienced an overall economic upturn, but is only partially supported using GDP\%. Another factor may be the selective termination of female pregnancies. The latitude gradient parallels that of neighbouring Europe but no theory has been put forward to convincingly explain this finding to date.
\end{abstract}

Key words: USSR; Birth Rate/*trends; Europelepidemiology; Infant/Newborn; Sex Ratio; Gross Domestic Product

\section{Introduction}

In mammals, gender is determined genetically, at conception. In humans, male births approximately occur in excess of female births (1). The male to female ratio of live births is generally expressed as the ratio of male live births divided by total live births $(\mathrm{M} / \mathrm{F})$, and for humans, this is anticipated to approximate 0.515 (2). The reason for this disparity is uncertain and the number of factors implicated are legion (3).

\section{Gender ratio at birth - latitude gradients}

It has been shown that $\mathrm{M} / \mathrm{F}$ varies in geographical space, demonstrating a latitude gradient (4), and that this gradient is different in Europe and North America, with more males born towards the south of Europe, in contrast with the North American continent where more males are born towards the north of the continent (2).

\section{Gender ratio at birth - secular trends}

Several studies have also been shown that $\mathrm{M} / \mathrm{F}$ varies in temporal fashion. The most striking findings have been a decline in $\mathrm{M} / \mathrm{F}$ over the second half of the 20 th century in various industrialised countries in Europe and North America (5).

\section{Specific European regions over the past 50 years}

More recent studies have shown a significant decreasing trend in $\mathrm{M} / \mathrm{F}$ for Czechoslovakia and the post-Czechoslovakian (Czech Republic and Slovakia) countries (6). In Yugoslavia and the post-Yugoslavian states, an increasing trend in $\mathrm{M} / \mathrm{F}$ was found prior to the breakup of the former Yugoslavia, followed by a decreasing trend thereafter (7). In addition, a study dealing with the United Kingdom showed that $\mathrm{M} / \mathrm{F}$ is decreasing in the British Isles, to the south more than to the north, with a reversal of the overall European latitude gradient, such that $\mathrm{M} / \mathrm{F}$ is higher in Scotland and Northern Ireland than in England and Wales, and the Republic of Ireland (8). Moreover, a Scandinavian study failed to show any localised latitude gradient with an overall decline in $\mathrm{M} / \mathrm{F}$ (9).

\section{The former Soviet republics}

The former Soviet republics (also known as the postSoviet states or the former Soviet Union) comprise 15 inde- 
pendent states that seceded from the Union of Soviet Socialist Republics (USSR) in its dissolution in December 1991.

This study identifies secular trends in $\mathrm{M} / \mathrm{F}$ in former Soviet republics from a World Health Organization (WHO) dataset. Trends by geographical latitude are also analysed as well as any relationship of percentage annual gross domestic product (GDP\%) growth and $\mathrm{M} / \mathrm{F}$. In this context, GDP\% is used as a measure for economic hardship or wellbeing within the populace.

The null hypotheses is that there were no significant geographical differences and no temporal variations in $\mathrm{M} / \mathrm{F}$. A second null hypothesis is that there was no relationship between $\mathrm{M} / \mathrm{F}$ and GDP\%.

\section{Methods}

\section{Data sources}

Annual male and female live births were obtained directly from WHO. Data was available for individual countries as per table 1, and included 115,167,569 births.

The former Soviet republics may be divided into the Russian Federation and four regions, the Baltic States (Estonia, Latvia and Lithuania), Eastern Europe (Belarus, Moldova and Ukraine), the Southern Caucasus (Armenia, Azerbaijan and Georgia) and Central Asia (Kazakhstan, Kyrgyzstan, Tajikistan, Turkmenistan and Uzbekistan).
Data for GDP\% was downloaded as an Excel sheet from the website of the World Bank (10).

\section{Statistics}

Excel was used for data entry and analysis. The quadratic equations of Fleiss were used for exact calculation of $95 \%$ confidence intervals for ratios (11).

Chi tests for trend were used for annual male and female births. These were performed using the Bio-MedStat Excel add-in for contingency tables. This add-in is based on the original work by Cochran and Armitage (Dr. Peter Slezák, Institute of Normal and Pathological Physiology, Slovak Academy of Sciences, personal communication) $(12,13)$.

Pearson correlation was only used to calculate the direction of any trends. Thus, only $r$ (correlation) statistic is shown.

Spearman correlations were carried out in the Statistical Package for the Social Sciences (SPSS), comparing GDP\% and $\mathrm{M} / \mathrm{F}$ for the years when both variables were available.

A $p$ value $\leq 0.05$ was taken to represent a statistically significant result.

\section{Results}

There have been increases in $\mathrm{M} / \mathrm{F}$ in all countries studied except for the Baltic States and Turkmenistan, as seen in table 1 , using chi tests for trend.

Tab. 1: Total male and female live births for the former Soviet Republics, and chi squared for trend analysis of the male to female ratio (male divided by total births)

\begin{tabular}{|c|c|c|c|c|c|c|c|}
\hline & Country & Years & Total Males & Total Females & chi & $\mathrm{p}$ & $\mathrm{r}$ \\
\hline \multirow{3}{*}{$\begin{array}{l}\text { Baltic } \\
\text { States } \\
53^{\circ} \mathrm{N}-59^{\circ} \mathrm{N}\end{array}$} & Estonia & $1981-2010$ & 251,030 & 237,116 & 0.9 & NS & 0.2 \\
\hline & Latvia & 1980-2008 & 430,656 & 409,007 & 1.1 & NS & 0.2 \\
\hline & Lithuania & 1981-2009 & 628,085 & 595,392 & 0.0 & NS & -0.1 \\
\hline \multirow{3}{*}{$\begin{array}{l}\text { Eastern } \\
\text { Europe } \\
44^{\circ} \mathrm{N}-57^{\circ} \mathrm{N}\end{array}$} & Belarus & 1981-2009 & $1,731,878$ & $1,632,802$ & 6.2 & 0.010 & 0.3 \\
\hline & Moldova & $1981-2010$ & 856,418 & 807,827 & 5.5 & 0.020 & 4 \\
\hline & Ukraine & 1981-2009 & $7,748,859$ & $7,313,506$ & 52.0 & $<0.0001$ & 0.6 \\
\hline \multirow{3}{*}{$\begin{array}{l}\text { Southern } \\
\text { Caucasus } \\
38^{\circ} \mathrm{N}-44^{\circ} \mathrm{N}\end{array}$} & Armenia & 1981-2009 & 787,677 & 720,346 & 571.2 & $<0.0001$ & 0.8 \\
\hline & Azerbaijan & $1981-2007$ & $2,003,869$ & $1,822,640$ & 1184.3 & $<0.0001$ & 0.9 \\
\hline & Georgia & $1981-2001$ & 768,907 & 710,717 & 346.8 & $<0.0001$ & 0.7 \\
\hline \multirow{5}{*}{$\begin{array}{l}\text { Central } \\
\text { Asia } \\
35^{\circ} \mathrm{N}-56^{\circ} \mathrm{N}\end{array}$} & Kazakhstan & 1982-2009 & $4,345,654$ & $4,114,748$ & 16.2 & $<0.0001$ & 0.4 \\
\hline & Kyrgyzstan & 1982-2009 & $1,615,722$ & $1,534,979$ & 21.1 & $<0.0001$ & 0.3 \\
\hline & Tajikistan & 1982-2004 & $2,144,443$ & $2,037,279$ & 15.6 & $<0.0001$ & 0.4 \\
\hline & Turkmenistan & 1982-1998 & $1,040,387$ & 992,029 & 1.1 & NS & 0.3 \\
\hline & Uzbekistan & $1982-2005$ & $7,617,487$ & $7,257,637$ & 171.4 & $<0.0001$ & 0.6 \\
\hline $\begin{array}{l}\text { Russian Federation } \\
41^{\circ} \mathrm{N}-82^{\circ} \mathrm{N}\end{array}$ & & 1980-2009 & $27,226,408$ & $25,784,064$ & 181.4 & $<0.0001$ & 0.7 \\
\hline
\end{tabular}


Tab. 2: 5 year total live births. Countries allocated as per table 1

\begin{tabular}{|c|c|c|c|c|c|c|c|}
\hline & & $1980-84$ & 1985-89 & 1990-94 & 1995-99 & $2000-04$ & 2005-09 \\
\hline \multirow{6}{*}{$\begin{array}{l}\text { Baltic } \\
\text { States } \\
53^{\circ} \mathrm{N}-59^{\circ} \mathrm{N}\end{array}$} & \multirow{6}{*}{$\begin{array}{l}\mathrm{M} \\
\mathrm{F} \\
\text { Total } \\
\mathrm{UCI} \\
\mathrm{M} / \mathrm{F} \\
\mathrm{LCI} \\
\end{array}$} & 217,112 & 316,596 & 256,674 & 182,124 & 166,356 & 170,909 \\
\hline & & 206,337 & 299,675 & 243,908 & 171,404 & 157,345 & 162,846 \\
\hline & & 423,449 & 616,271 & 500,582 & 353,528 & 323,701 & 333,755 \\
\hline & & 0.51423 & 0.51498 & 0.51414 & 0.51681 & 0.51564 & 0.51378 \\
\hline & & 0.51272 & 0.51373 & 0.51275 & 0.51516 & 0.51392 & 0.51208 \\
\hline & & 0.51122 & 0.51248 & 0.51137 & 0.51351 & 0.51220 & 0.51038 \\
\hline \multirow{6}{*}{$\begin{array}{l}\text { Eastern } \\
\text { Europe } \\
44^{\circ} \mathrm{N}-57^{\circ} \mathrm{N}\end{array}$} & \multirow{6}{*}{$\begin{array}{l}\mathrm{M} \\
\mathrm{F} \\
\text { Total } \\
\mathrm{UCI} \\
\mathrm{M} / \mathrm{F} \\
\mathrm{LCI}\end{array}$} & $1,545,336$ & $2,576,411$ & $2,013,051$ & $1,503,554$ & $1,353,486$ & $1,345,317$ \\
\hline & & $1,466,659$ & $2,438,780$ & $1,899,365$ & $1,413,926$ & $1,270,285$ & $1,265,120$ \\
\hline & & $3,011,995$ & $5,015,191$ & $3,912,416$ & $2,917,480$ & $2,623,771$ & $2,610,437$ \\
\hline & & 0.51363 & 0.51416 & 0.51502 & 0.51593 & 0.51646 & 0.51597 \\
\hline & & 0.51306 & 0.51372 & 0.51453 & 0.51536 & 0.51586 & 0.51536 \\
\hline & & 0.51250 & 0.51328 & 0.51403 & 0.51479 & 0.51525 & 0.51475 \\
\hline \multirow{6}{*}{$\begin{array}{l}\text { Southern } \\
\text { Caucasus } \\
38^{\circ} \mathrm{N}-44^{\circ} \mathrm{N}\end{array}$} & \multirow{6}{*}{$\begin{array}{l}\mathrm{M} \\
\mathrm{F} \\
\text { Total } \\
\mathrm{UCI} \\
\mathrm{M} / \mathrm{F} \\
\mathrm{LCI}\end{array}$} & 568,445 & 914,017 & 809,430 & 592,381 & 430,666 & 245,514 \\
\hline & & 536,533 & 859,370 & 755,050 & 520,835 & 370,364 & 211,551 \\
\hline & & $1,104,978$ & $1,773,387$ & $1,564,480$ & $1,113,216$ & 801,030 & 457,065 \\
\hline & & 0.51537 & 0.51614 & 0.51816 & 0.53306 & 0.53873 & 0.53860 \\
\hline & & 0.51444 & 0.51541 & 0.51738 & 0.53213 & 0.53764 & 0.53715 \\
\hline & & 0.51351 & 0.51467 & 0.51660 & 0.53121 & 0.53655 & 0.53571 \\
\hline \multirow{6}{*}{$\begin{array}{l}\text { Central } \\
\text { Asia } \\
35^{\circ} \mathrm{N}-56^{\circ} \mathrm{N}\end{array}$} & \multirow{6}{*}{$\begin{array}{l}\mathrm{M} \\
\mathrm{F} \\
\text { Total } \\
\mathrm{UCI} \\
\mathrm{M} / \mathrm{F} \\
\mathrm{LCI}\end{array}$} & $2,099,660$ & $3,194,427$ & $3,831,366$ & $3,276,714$ & $2,638,447$ & $1,723,079$ \\
\hline & & $2,008,057$ & $3,045,375$ & $3,663,259$ & $3,103,626$ & $2,491,670$ & $1,624,685$ \\
\hline & & $4,107,717$ & $6,239,802$ & $7,494,625$ & $6,380,340$ & $5,130,117$ & $3,347,764$ \\
\hline & & 0.51163 & 0.51234 & 0.51157 & 0.51395 & 0.51474 & 0.51523 \\
\hline & & 0.51115 & 0.51194 & 0.51122 & 0.51356 & 0.51431 & 0.51470 \\
\hline & & 0.51067 & 0.51155 & 0.51086 & 0.51318 & 0.51387 & 0.51416 \\
\hline \multirow{6}{*}{$\begin{array}{l}\text { Russian } \\
\text { Federation } \\
41^{\circ} \mathrm{N}-82^{\circ} \mathrm{N}\end{array}$} & \multirow{6}{*}{$\begin{array}{l}\mathrm{M} \\
\mathrm{F} \\
\text { Total } \\
\mathrm{UCI} \\
\mathrm{M} / \mathrm{F} \\
\mathrm{LCI}\end{array}$} & $5,967,737$ & $6,089,469$ & $4,169,305$ & $3,306,807$ & $3,568,010$ & $4,125,080$ \\
\hline & & $5,687,630$ & $5,780,620$ & $3,939,199$ & $3,119,561$ & $3,359,365$ & $3,897,689$ \\
\hline & & $11,655,367$ & $11,870,089$ & $8,108,504$ & $6,426,368$ & $6,927,375$ & $8,022,769$ \\
\hline & & 0.51230 & 0.51329 & 0.51453 & 0.51496 & 0.51543 & 0.51452 \\
\hline & & 0.51202 & 0.51301 & 0.51419 & 0.51457 & 0.51506 & 0.51417 \\
\hline & & 0.51173 & 0.51273 & 0.51385 & 0.51418 & 0.51469 & 0.51383 \\
\hline
\end{tabular}

Tab. 3: Summary statistics and significance testing

\begin{tabular}{|l|c|c|c|c|c|}
\hline & Baltic States & Eastern Europe & Southern Caucasus & Central Asia & Russian Federation \\
\hline $\mathrm{M}$ & $1,309,771$ & $10,337,155$ & $3,560,453$ & $16,763,693$ & $27,226,408$ \\
\hline $\mathrm{F}$ & $1,241,515$ & $9,754,135$ & $3,253,703$ & $15,936,672$ & $25,784,064$ \\
\hline Total & $2,551,286$ & $20,091,290$ & $6,814,156$ & $32,700,365$ & $53,010,472$ \\
\hline $\mathrm{UCI}$ & 0.51399 & 0.51473 & 0.52288 & 0.51282 & 0.51374 \\
\hline $\mathrm{M} / \mathrm{F}$ & 0.51338 & 0.51451 & 0.52251 & 0.51265 & 0.51360 \\
\hline $\mathrm{LCI}$ & 0.51276 & 0.51429 & 0.52213 & 0.51247 & 0.51347 \\
\hline $\mathrm{r}$ & 0.1 & 0.7 & 0.9 & 0.8 & 0.8 \\
\hline $\mathrm{chi}$ trend & 739 & 65 & 2123 & 189 & 181 \\
\hline $\mathrm{p}$ & $<0.0001$ & $<0.0001$ & $<0.0001$ & $<0.0001$ & $<0.0001$ \\
\hline
\end{tabular}


Tab. 4: Spearman correlation between percentage annual gross domestic product (GDP\%) growth and M/F

\begin{tabular}{|c|c|c|c|c|c|c|c|c|}
\hline & Estonia & Latvia & Lithuania & Belarus & Moldova & Ukraine & Armenia & \\
\hline Years & 1996-2010 & 1996-2008 & 1991-2009 & 1991-2009 & 1991-2008 & 1988-2008 & 1991-2008 & \\
\hline $\mathrm{r}$ & -0.55 & -0.04 & -0.02 & -0.38 & 0.3 & 0.07 & 0.55 & \\
\hline \multirow[t]{2}{*}{$\mathrm{p}$} & 0.032 & 0.8 & 0.9 & 0.11 & 0.08 & 0.76 & 0.018 & \\
\hline & Azerbaijan & Georgia & Kazakhstan & Kyrgyzstan & Tajikistan & Turkmenistan & Uzbekistan & $\begin{array}{c}\text { Russian } \\
\text { Federation }\end{array}$ \\
\hline Years & 1991-2006 & 1991-2001 & 1991-2009 & 1991-2009 & 1986-2004 & 1988-1997 & 1988-2005 & 1990-2009 \\
\hline $\mathrm{r}$ & 0.89 & 0.5 & 0.04 & 0.09 & -0.27 & 0.13 & 0.66 & 0.34 \\
\hline $\mathrm{p}$ & $<0.0001$ & 0.12 & 0.88 & 0.67 & 0.27 & 0.67 & 0.003 & 0.14 \\
\hline
\end{tabular}

Years denotes years available wherein both variables where available

Countries were grouped as described above, and five year trends for live births are shown in table 2. Chi testing again shows significant increasing trend in $\mathrm{M} / \mathrm{F}$ was found in all regions (Table 3 ).

The data shows that $\mathrm{M} / \mathrm{F}$ is lower in the three more northern regions (Russian Federation, Baltic States and Central Asia: M/F 0.51324, 0.51335-0.51314) than the two more southern regions (Southern Caucasus and Eastern Europe: M/F 0.51654, 0.51635-0.51672). A $2 \times 2$ chi test showed that this latitude gradient was significant $(\mathrm{chi}=895$, $\mathrm{p}<0.0001)$.

The male births in excess of that which would be expected for this entire region, based on an anticipated M/F of around 0.515 , were calculated at 11,3818.

There was a significant positive correlation between GDP $\%$ and M/F for Armenia, Azerbaijan and Uzbekistan. There was a significant negative correlation in Estonia (Table 4).

\section{Discussion}

The male fetus is more fragile and therefore more prone to be miscarried under external toxic influences than the female fetus (3). Moreover, the male fetus is at greater risk of all obstetric complications. Despite these adverse factors, males are invariably born in excess of females (3), implying an even higher conception rate of males. It has been therefore been proposed that $\mathrm{M} / \mathrm{F}$ may serve as a sentinel health marker (15).

An earlier study dealing with Europe had shown a higher incidence of male births in warmer southern Europe than in northern Europe (4), and this was confirmed by a larger study that spanned the second half of the 20th century (2). However, the latter study showed the converse latitude gradient, in that more males are born in higher and cooler latitudes in the Northern American continent than in the southern parts of this continent (2).

Interestingly, Scandinavian studies noted increasing trends before the second half of the 20th century and decreasing trends after 1950 (16). However, this data did not exist (except for as an amalgamation as the USSR) since these countries only came into existence in the early 1980s.

Although there is some overlap in latitude ranges between the countries and regions that are investigated in this study, there is a significant $\mathrm{M} / \mathrm{F}$ gradient that follows that of Europe, with less males born in the colder northern regions than in the warmer southern regions.

Moreover, contrary to that shown in Europe and the North American continent, this study shows a significant overall secular rise in $\mathrm{M} / \mathrm{F}$, despite the short time span available for analysis (1980-2009).

In this study, inevitably, countries with quite different racial compositions have been amalgamated and this may have attenuated the results obtained since it has been suggested that M/F may also vary by race (17).

A veritable plethora of external factors that influence $\mathrm{M} / \mathrm{F}$ have been described (18). A hypothesis that may partially explain these findings is the potential for caloric availability per capita to increase $\mathrm{M} / \mathrm{F}$ as it has been shown that the availability of food correlates positively with $M / F$ (19). This is supported by studies that show the corollary, that is, that contracting economies favour a decline in $\mathrm{M} / \mathrm{F}(20)$.

The increasing $\mathrm{M} / \mathrm{F}$ noted in the former Soviet Republics might potentially be linked with an improvement in the overall socio-economic status of these regions since their emergence from rigorous communist rule. However, an attempt to analyse this hypothesis using GDP\% was only partially successful, finding a positive correlation for 3 out of 15 countries and a negative correlation in 1 country. Failure to find any significant relationship may be due to the small span of years available, a type 2 error, or to the possibility that GDP\% is too crude a surrogate marker for the economic wellbeing or otherwise of any given population. Yet another factor that has been implicated in the Southern Caucasus region is gender-selective abortion, with the antenatal determination of gender and the 
selective termination of female foetuses in societies which prize males more than females (21).

A study focussing on $\mathrm{M} / \mathrm{F}$ in the Novosibirsk region over the period $1961-2008\left(52-58^{\circ} \mathrm{N}, 75-8^{\circ} \mathrm{E}\right.$, population in 2008: 2,639,857, 79\% urban, 54\% female, 93\% Russian) showed a declining trend up to the early 1980 s, with an increasing trend thereafter, confirming the findings of this study (22).

Other factors that may potentially be implicated for causing a rise in $\mathrm{M} / \mathrm{F}$ include a falling birth rate, but this has not been causally related to $\mathrm{M} / \mathrm{F}$ in studies dealing with this topic. Increasing maternal age has, however, been found to decrease $\mathrm{M} / \mathrm{F}$ as well as overall family size. However, this data was not available for analysis.

Early work indicated that where prenatal (fetal) losses are low, as in developed countries with higher standards of care, $\mathrm{M} / \mathrm{F}$ tends to be higher than in countries wherein lower standards of living (and hence poorer healthcare) seemed to increase $\mathrm{M} / \mathrm{F}$ (23). However, more recent work shows that improving economies (with enhanced healthcare, including antenatally) increases $\mathrm{M} / \mathrm{F}(14,18)$. Improved healthcare also gives access to the possibility of sex-selective termination, but data with regard to the availability of such services was not available for comment. Naturally, as economies in these regions flourish, innovative techniques such as sex-selective abortion may further influence M/F (24).

To the author's knowledge, this is the first attempt to link GDP\% to $\mathrm{M} / \mathrm{F}$. While this paper further expands on secular trends in $\mathrm{M} / \mathrm{F}$, no easy explanation can be proposed for an overall increasing $\mathrm{M} / \mathrm{F}$ in this geographical region other than that of the mitigation of socioeconomic conditions and gender-selective abortion. The latitude gradient, while consistent with that in neighbouring Europe, also remains inexplicable.

\section{Acknowledgements}

Mie Inoue and Gauden Galea from the World Health Organisation.

\section{References}

1. Parkes AS. The mammalian sex ratio. Hum Reprod 1926; 2: 1-51.

2. Grech V, Savona-Ventura C, Vassallo-Agius P. Unexplained differences in the sex ratio at birth in Europe and North America. Br. Med. J 2002; 324: 1010-1011.

3. James WH. Parental hormone levels and mammalian sex ratios at birth. J Theor Biol 1989; 139: 59-67.

4. Grech V, Vassallo-Agius P, Savona-Ventura C. Declining male births with increasing geographical latitude in Europe. J. Epidemiol. Community Health 2000; $54: 244-246$

5. Grech V, Vassallo-Agius P, Savona-Ventura C. Secular trends in sex ratios at birth in North America and Europe over the second half of the 20th century. J Epidemiol Community Health 2003; 57: 612-5.

6. Grech V. Secular trends and latitude gradients in sex ratios at birth in Czechoslovakia and the post-Czechoslovakian states. Acta Medica (Hradec Kralove) 2012; 55(3): 138-41.

7. Grech V. Secular trends and latitude gradients in the male-female ratio at birth in Yugoslavia and the ex-Yugoslavian states. Acta Medica (Hradec Kralove) in press.

8. Grech V. Sex ratios at birth in the British Isles over the past sixty years. Eur J Pediatr. 2012 Dec 30. [Epub ahead of print]

9. Grech V. Sex ratios at birth in Scandinavia over the past sixty years. Scand J Public Health. 2012; 40: 761-4.

10. The World Bank [Internet]. Data. GDP growth (annual \%). Available from: http:// data.worldbank.org/indicator/NY.GDP.MKTP.KD.ZG.

11. Fleiss JL. Statistical methods for rates and proportions. New York: John Wiley and Sons, 1981: 14-15 (2nd edition).

12. Cochran WG. Some methods for strengthening the common chi-squared tests Biometrics 1954; 10: 417-451.

13. Armitage P. Tests for Linear Trends in Proportions and Frequencies. Biometrics. 1955; 11: 375-386.

14. James WH. The human sex ratio. Part 1: A review of the literature. Hum Biol 1987; 59: 721-752.

15. Davis DL, Gottlieb MB, Stampnitzky JR. Reduced ratio of male to female births in several industrial countries: a sentinel health indicator? JAMA 1998; 279: $1018-1023$.

16. Fellman J, Eriksson AW. Temporal trends in the secondary sex ratio in Nordic countries. Biodemography Soc Biol 2011; 57: 143-54.

17. Visaria PM. Sex ratio at birth in territories with a relatively complete registration. Eugen Q 1967; 14: 132-42.

18. James WH. Evidence that mammalian sex ratios at birth are partially controlled by parental hormone levels around the time of conception. J Endocrinol 2008; 198: 3-15.

19. Williams RJ, Gloster SP. Human sex ratio as it relates to caloric availability. Soc Biol 1992; 39: 285-291.

20. Catalano RA. Sex ratios in the two Germanies: a test of the economic stress hypothesis. Hum Reprod 2003; 18: 1972-5.

21. Michael M, King L, Guo L, McKee M, Richardson E, Stuckler D. The mystery of missing female children in the Caucasus: an analysis of sex ratios by birth order Int Perspect Sex Reprod Health 2013; 39: 97-102.

22. Melnikov VN. Birth and Death in Siberia in the Context of Seasonality. Novosibirsk, Russia. Siberia; Publishing House of Siberian Branch of the Russian Academy of Sciences: 2012.

23. Hawley, AH. Population composition. In Hauser PM, Duncan OD (eds.) The Study of Population: An Inventory and Appraisal. Chicago; University of Chicago Press: 1959. pp. 361-382.

24. World Health Organization. Preventing gender-biased sex selection: An interagency statement OHCHR. WHO: Geneva: 2011.

Received: 14/09/2013

Accepted in revised form: 15/11/2013

\section{Corresponding author:}

Prof. Victor Grech, Department of Paediatrics, Mater Dei Hospital, Malta; e-mail: victor.e.grech@gov.mt 